\title{
Urban Landuse: A Model Analysis of Panskura Municipality in West Bengal
}

\author{
Dr. Nirmalya Das \\ Assistant Professor, Dept. of Geography, Panskura Banamali College, Purba Medinipur, West Bengal
}

\begin{abstract}
Rapid urban growth is a common phenomenon of the developing countries. Now, in India about 30 percent of the people are living in urban areas but in all respect urbanization does not mean the higher economic growth. Increasing urbanization means a lot of land has been converted from rural to urban. This conversion is responsible for quick changes of landuse and land cover in urban areas. So, information of land use and land cover change is highly necessary for different groups. Analyzing and modelling these changes, therefore, provide better information for urban planners and decision makers to design strategies and solutions to manage the impacts of land use and land cover changes in both spatial and temporal scales. Viewing the present scenario, the author has tried to focus on urban land use concentration model and ultimately develop the pattern of urban landuse specialization and diversification status.
\end{abstract}

Keyword: Urban growth, landuse changes, landuse concentration, landuse specialization.

\section{Introduction}

Land use simply means the utilization of land devoted to human activities. Urban growth causes landuse variation than the rural areas. Since 1970 's, the rapid urbanization in developing countries and other anthropogenic-environment interactions are responsible for quick changes in landuse and land cover in urban areas. In spite of its small area coverage relative to the earth's surface, dynamic urban growth processes, particularly the expansion of urban population in a larger extent and urbanized area, have a significant impact on natural and human environment at all geographic scales (Harold et al, 2005). Associated with the rapid expansion of urbanization, a lot of land has been converted from rural to urban. From the land use and land cover change point of view, expansion of urban areas is of greater importance because of its strong effect on other land cover classes, such as agricultural lands, non built areas, forests and others. Analyzing and modelling these changes, therefore, provide better information for urban planners and decision makers to design strategies and solutions to manage the impacts of land use and land cover changes in both spatial and temporal scales. Understanding the rapid growth dynamics, developments of urban sprawl and quantifying the spatial extent of urbanization requires a geospatial tool (Araya and Cabral, 2010). Since accurate and timely information of land use and land cover change is highly necessary to many groups, remotely sensed data can be used as it provides the land cover information. The urban areas are marked by their distinctive pattern of land use. The total land use types may be grouped into following categories and these are: (i) open space, (ii) residential area, (iii) commercial area, (iv) water bodies, (v) industrial area, and (vi) agricultural area.

\section{Study Area}

Panskura municipality is the study area which came into existence on 2002 with 17 wards of Purba Medinipur District of West Bengal. Panskura is located at $22.42^{\circ} \mathrm{N}$ latitude and $87.7^{\circ} \mathrm{E}$ longitude. It is situated on the NH6 on the way from Kolkata to Kharagpur. The District is surrounded by Kolaghat block in the north, Kasai River in the west. It has an average elevation of 7 metres from the sea level.

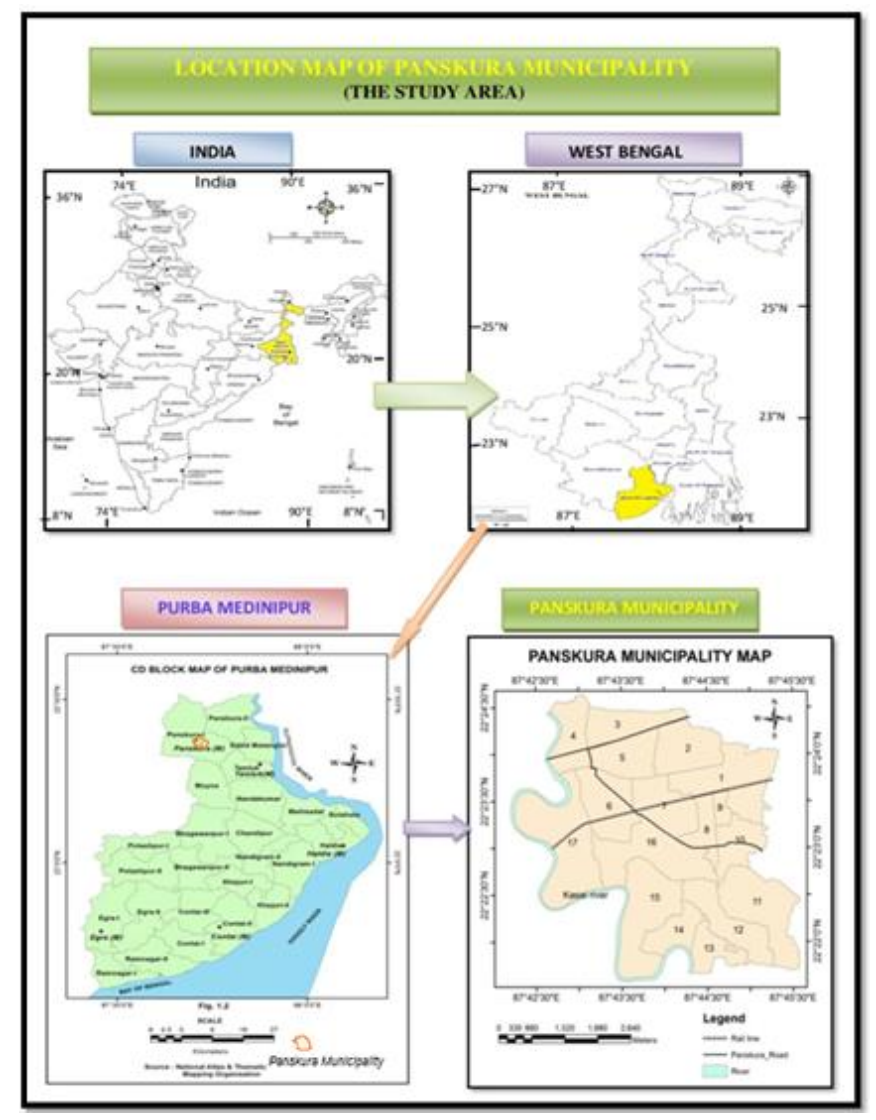

Figure 1

\section{Objectives of the study}

The main objectives of the study are:

1) To analyze the urban growth of the study area

2) T o study the urban landuse concentration pattern

3) To assess the present landuse concentration for future planning.

\section{Volume 5 Issue 6, June 2016 www.ijsr.net}




\section{International Journal of Science and Research (IJSR) \\ ISSN (Online): 2319-7064}

Index Copernicus Value (2013): 6.14 | Impact Factor (2015): 6.391

\section{Database and Methodology}

To study the above objectives, various types of data are used for concentration analysis. The Google Earth image and LISS -III image of ISRO-Bhuvan have been used for landuse analysis with the help of Arc GIS software. The secondary data are also collected from Panskura Municipality, District Census Handbook and District Statistical Handbook of Purba Medinipur. The cartographic and statistical techniques, remote sensing and GIS techniques are used for data and image analysis.

\section{Urban Analysis}

Municipality constituted on $3^{\text {rd }}$ December, 2001 but it has started functioning from $8^{\text {th }}$ June, 2002. Panskura is a small town of Purba Medinipur district which is semi urban in nature with agricultural economic background. The livelihood of the common people is agriculture and commercial activities. Varieties of flowers and green vegetable are grown around the municipality area and most of the agro-based products are supplied to Kolkata. Local vegetable wholesale market is the main trade of this town. The vegetable market of Panskura is the $2^{\text {nd }}$ largest in West Bengal. Though it is a small and newly developed urban center but the population growth is high due to the increasing commercial activities and nearness of Southeastern railway and National Highway - 6. As per 2001 and 2011 census the municipality registered 52155 and 57932 population respectively. In 2011, there are 60 slum pockets with the population of 33022 which indicate the absence of urban basic amenities.

Table 1: Area, population and density difference of population of Panskura Municipality, 2001 to 2011

\begin{tabular}{|c|c|c|c|c|c|c|}
\hline $\begin{array}{c}\text { Ward } \\
\text { No }\end{array}$ & $\begin{array}{c}\text { Area } \\
(\mathrm{sq} \mathrm{km})\end{array}$ & $\begin{array}{c}\text { Population } \\
(2001)\end{array}$ & $\begin{array}{c}\text { Population } \\
(2011)\end{array}$ & $\begin{array}{c}\text { Population Density } \\
\text { /sq km (2011) }\end{array}$ & $\begin{array}{c}\text { Population Density } \\
\text { / sq km (2001) }\end{array}$ & $\begin{array}{c}\text { Density Difference } \\
(2011-2001)\end{array}$ \\
\hline 1 & 1.62 & 2985 & 4546 & 2809 & 1845 & 965 \\
\hline 2 & 0.98 & 3442 & 4190 & 4266 & 3505 & 762 \\
\hline 3 & 0.67 & 3136 & 2933 & 4403 & 4708 & -305 \\
\hline 4 & 0.74 & 1831 & 2515 & 3421 & 2491 & 930 \\
\hline 5 & 0.77 & 3650 & 4005 & 5207 & 2218 & 462 \\
\hline 6 & 1.12 & 2493 & 2651 & 2358 & 2839 & 654 \\
\hline 7 & 0.93 & 2641 & 3249 & 3493 & 8111 & 130 \\
\hline 8 & 0.37 & 2994 & 3042 & 8241 & 6186 & 7737 \\
\hline 9 & 0.22 & 1921 & 3655 & 16308 & 2551 & -941 \\
\hline 10 & 0.63 & 3910 & 3315 & 5244 & 2602 & 225 \\
\hline 11 & 1.58 & 4029 & 4384 & 2776 & 5402 & 199 \\
\hline 12 & 1.02 & 2641 & 2843 & 2801 & 4231 & 886 \\
\hline 13 & 0.44 & 2372 & 2761 & 6288 & 2295 & 517 \\
\hline 14 & 0.52 & 2192 & 2460 & 4748 & 3046 & 68 \\
\hline 15 & 1.62 & 3718 & 3865 & 2386 & 1503 & -356 \\
\hline 16 & 1.6 & 4859 & 4968 & 3115 & & \\
\hline 17 & 2.22 & 3341 & 2550 & 1147 & & \\
\hline
\end{tabular}

Source: District census handbook, $2001 \& 2011$

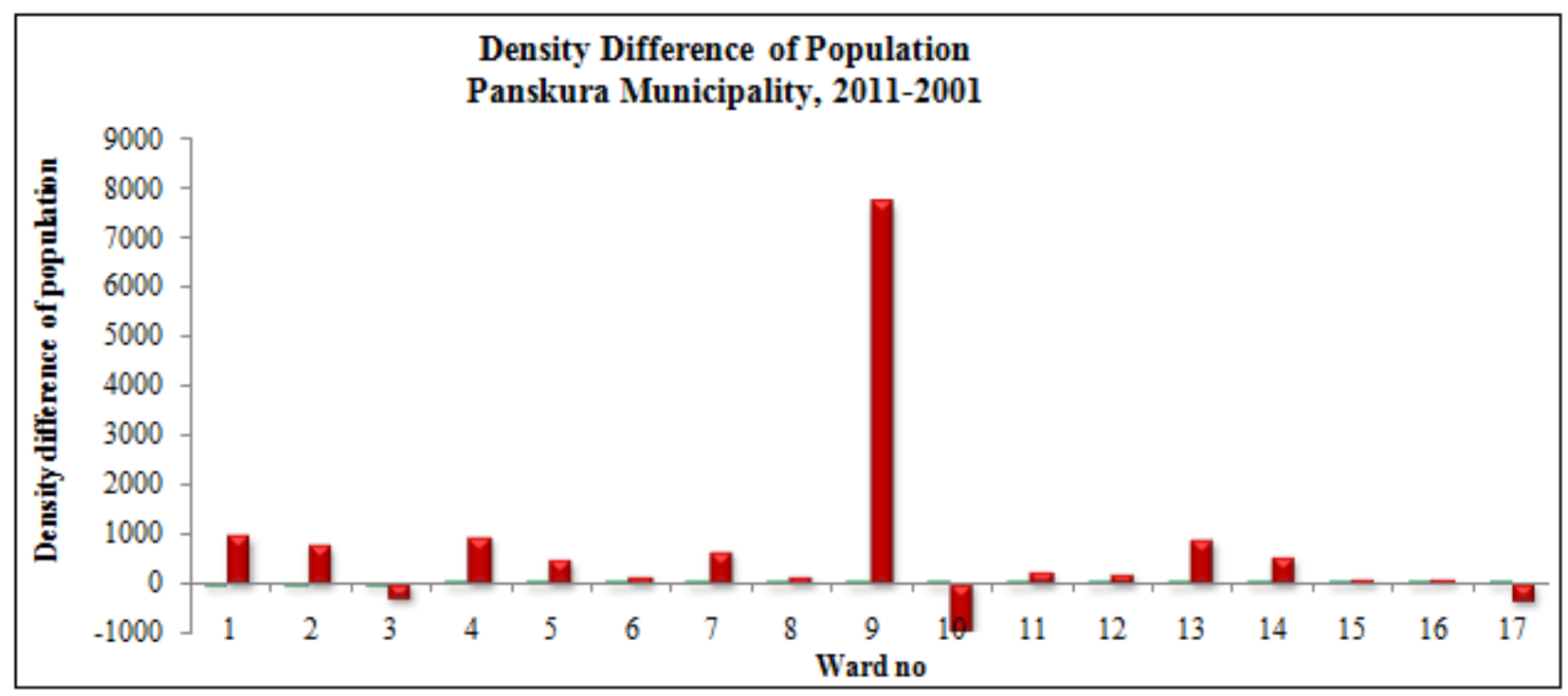

Figure 2

Volume 5 Issue 6, June 2016 www.ijsr.net 


\section{International Journal of Science and Research (IJSR) \\ ISSN (Online): 2319-7064}

Index Copernicus Value (2013): 6.14 | Impact Factor (2015): 6.391

\section{Urban landuse}

Urban land use consists of two elements; the nature of land use, which relates to the activities that is taking place in the urban areas and the level of spatial accumulation, which indicates their intensity and concentration. Different part of the urban area has a various level of spatial concentrations corresponding to land uses. Several models of urban land use have been developed by economist and geographers over time with increased levels of complexity. Urban land utilization is currently indicating the process of land exploration, usage, and protection in the course of city construction and development. The ward wise land use types of Haldia municipality show a spatial distribution pattern where residential concentration occurred in all the wards, but both commercial and industrial activities are absent in some of the wards. Human beings are the main element for changing the landscape of any urban area and then residential, industrial and commercial land use analyses are most important. For analyzing the residential, industrial and commercial landuse pattern of Panskura municipality the concentration index (CI) (Sinha, B.N, 1970) may be conveniently used to measure the intensity of uses of land within the urban center based on area under individual landuse and total utilized area of the urban centre. The identification of ward wise major land use pattern of the study area has been measured from the recent Google image and LISS - III image with the help of Arc GIS software. After measuring the utilized land for major purposes of different wards the concentration index have been calculated using Sinha's method which are stated below:
C.I. for Residential Use $=\frac{R / U}{T R / T U}$

Where,

$\mathrm{R}=$ Residential area of $\mathrm{x}$ ward

$\mathrm{TR}=$ Total Residential area of the town.

$\mathrm{U}=$ Utilized area of the $\mathrm{x}$ ward.

$\mathrm{TU}=$ Total Utilized area of the town

\section{C.I. for Commercial Use $=\frac{C / U}{T C / T U}$}

Where,

$\mathrm{C}=$ Commercial area of $\mathrm{x}$ ward

$\mathrm{TC}=$ Total commercial area of the town

$\mathrm{U}=\mathrm{Utilized}$ area of the $\mathrm{x}$ ward

$\mathrm{TU}=$ Total Utilized area of the town

\section{C.I. for Industrial Use $=\frac{I / U}{T I / T U}$}

Where,

$\mathrm{I}=$ Industrial area of the $\mathrm{x}$ ward.

$\mathrm{TI}=$ Total industrial area of the town

$\mathrm{U}=\mathrm{Utilized}$ area of the ward.

$\mathrm{TU}=$ Total utilized area of the town

\section{C.I. for Agricultural Use $=\frac{A / U}{T A / T U}$}

Where,

$\mathrm{CA}=$ Concentration of Agriculture

$\mathrm{A}=$ Agricultural area of the $\mathrm{x}$ ward.

$\mathrm{TA}=$ Total Agricultural area of the town

$\mathrm{U}=$ Utilized area of the ward.

$\mathrm{TU}=$ Total utilized area of the town

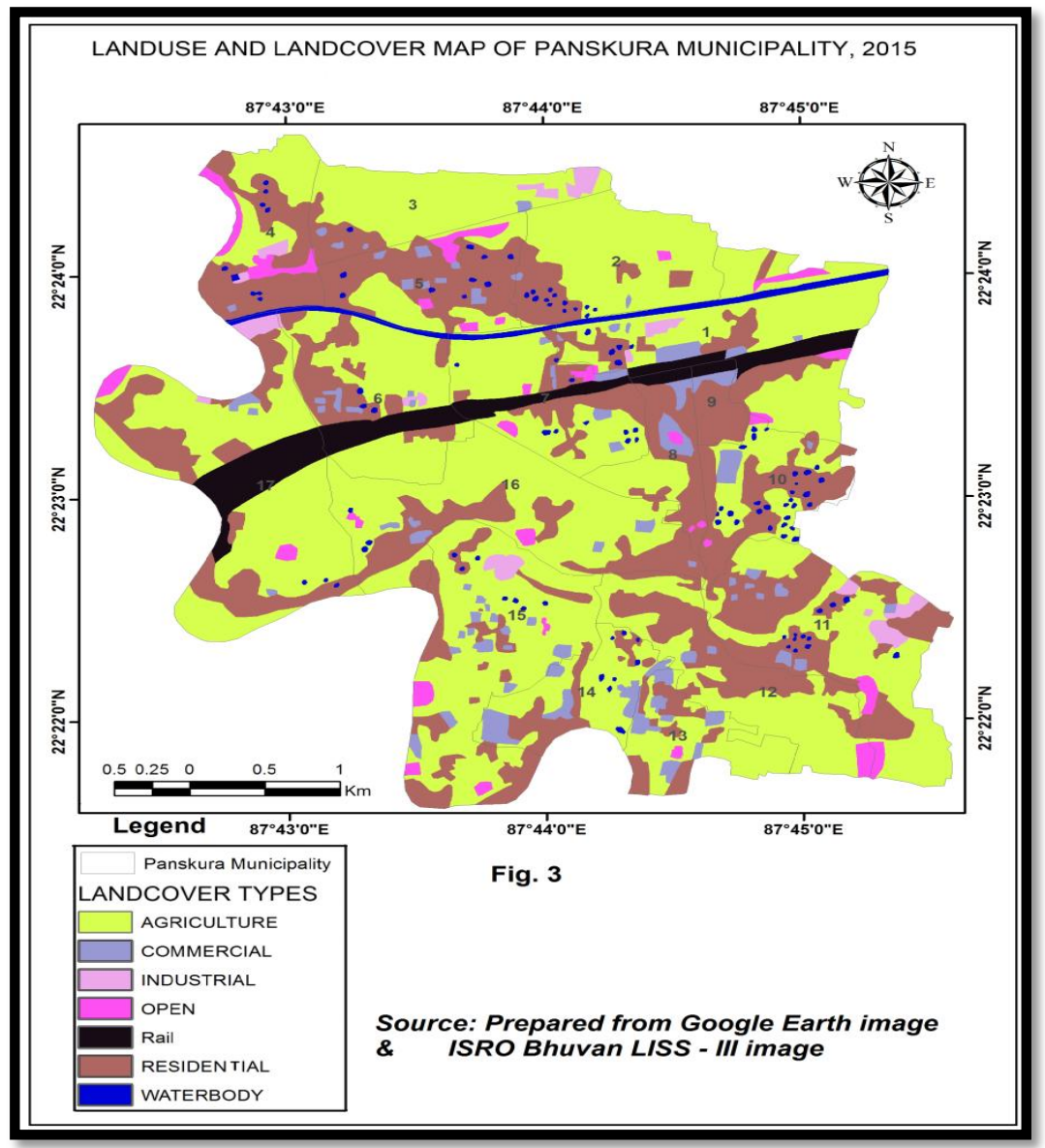

Volume 5 Issue 6, June 2016 www.ijsr.net 


\section{International Journal of Science and Research (IJSR) \\ ISSN (Online): 2319-7064}

Index Copernicus Value (2013): 6.14 | Impact Factor (2015): 6.391

Table 2: Ward wise landuse area (sq. km) of Panskura Municipality, 2015

\begin{tabular}{|c|c|c|c|c|c|c|c|c|}
\hline Ward No & Ward Area & Open & Residential & Commercial & Water body & Industrial & Agriculture & Rail \\
\hline 1 & 1.80 & 0.05 & 0.28 & 0.06 & 0.12 & 0.03 & 1.09 & 0.17 \\
\hline 2 & 1.16 & 0.01 & 0.22 & 0.01 & 0.01 & 0.00 & 0.91 & 0.00 \\
\hline 3 & 0.94 & 0.00 & 0.13 & 0.02 & 0.00 & 0.06 & 0.73 & 0.00 \\
\hline 4 & 0.91 & 0.09 & 0.45 & 0.00 & 0.02 & 0.03 & 0.32 & 0.00 \\
\hline 5 & 0.95 & 0.07 & 0.54 & 0.04 & 0.02 & 0.00 & 0.28 & 0.00 \\
\hline 6 & 1.30 & 0.00 & 0.33 & 0.03 & 0.04 & 0.01 & 0.72 & 0.17 \\
\hline 7 & 1.11 & 0.03 & 0.25 & 0.04 & 0.04 & 0.00 & 0.63 & 0.12 \\
\hline 8 & 0.55 & 0.01 & 0.26 & 0.06 & 0.00 & 0.00 & 0.17 & 0.04 \\
\hline 9 & 0.20 & 0.00 & 0.14 & 0.02 & 0.00 & 0.00 & 0.00 & 0.03 \\
\hline 10 & 0.81 & 0.01 & 0.40 & 0.04 & 0.04 & 0.00 & 0.31 & 0.00 \\
\hline 11 & 1.76 & 0.05 & 0.70 & 0.05 & 0.01 & 0.08 & 0.86 & 0.00 \\
\hline 12 & 1.19 & 0.03 & 0.45 & 0.01 & 0.00 & 0.00 & 0.69 & 0.00 \\
\hline 13 & 0.62 & 0.01 & 0.16 & 0.09 & 0.00 & 0.00 & 0.36 & 0.00 \\
\hline 14 & 0.70 & 0.00 & 0.17 & 0.12 & 0.01 & 0.00 & 0.39 & 0.00 \\
\hline 15 & 1.90 & 0.05 & 0.40 & 0.09 & 0.01 & 0.04 & 1.30 & 0.00 \\
\hline 16 & 1.77 & 0.02 & 0.49 & 0.04 & 0.00 & 0.00 & 1.21 & 0.00 \\
\hline 17 & 2.40 & 0.04 & 0.58 & 0.02 & 0.01 & 0.04 & 1.39 & 0.31 \\
\hline
\end{tabular}

Source: Municipality Map, Google Image, ISRO Bhuvan LISS - III image.

Table 3: Wardwise concentration value of different types of landuse

\begin{tabular}{|c|c|c|c|c|}
\hline $\begin{array}{c}\text { Ward } \\
\text { No }\end{array}$ & $\begin{array}{c}\text { Residential } \\
\text { concentration }\end{array}$ & Commercial concentration & $\begin{array}{c}\text { Industrial } \\
\text { concentration }\end{array}$ & $\begin{array}{c}\text { Agriculture } \\
\text { concentration }\end{array}$ \\
\hline 1 & 6.48 & 0.92 & 1.10 & 1.07 \\
\hline 2 & 8.09 & 0.14 & 0.00 & 1.38 \\
\hline 3 & 5.85 & 0.46 & 4.33 & 1.37 \\
\hline 4 & 20.67 & 0.08 & 1.93 & 0.62 \\
\hline 5 & 23.65 & 1.14 & 0.00 & 0.52 \\
\hline 6 & 10.61 & 0.53 & 0.72 & 0.97 \\
\hline 7 & 9.29 & 0.96 & 0.00 & 0.00 \\
\hline 8 & 19.96 & 3.10 & 0.00 & 0.03 \\
\hline 9 & 30.17 & 3.18 & 0.00 & 0.69 \\
\hline 10 & 20.70 & 1.34 & 0.00 & 0.87 \\
\hline 11 & 16.64 & 0.74 & 3.10 & 1.03 \\
\hline 12 & 15.86 & 0.32 & 0.00 & 1.03 \\
\hline 13 & 10.57 & 3.91 & 0.00 & 1.00 \\
\hline 14 & 10.27 & 4.54 & 0.00 & 1.21 \\
\hline 15 & 8.79 & 1.28 & 1.50 & 1.20 \\
\hline 16 & 11.60 & 0.64 & 0.00 & 1.02 \\
\hline 17 & 10.06 & 0.26 & 1.21 & \\
\hline
\end{tabular}

Source: Calculated according to Sinah's method based on wardwise utilized land

\section{Landuse Concentration}

Land is the most vital resource of any region based on its utilization. Urban landuse pattern is a complex one because of their multi-functioning attributes. The multi-functional patterns are city size based, i.e. larger the size more complexity or increasing multi-functional land uses where as smaller the urban size less the complexity or more single land uses pattern is dominant. Panskura municipality is a newly developed small urban center of Purba Medinipur district with the dominance of agricultural activities. It is the second largest vegetable market of West Bengal which signifies the rural background of the urban center. Table no 2 and 3 shows the wardwise actual landuse and concentration of major land utilization value. Residential development is the dominant landuse within the municipality. In some places, the boundary is clear between new housing developments and intensively used agricultural areas, but the boundary may be difficult to demarcate where residential development occurs in small isolated units over an area of mixed or less intensive uses. The term 'commercial occupancy' is used to indicate the concentration of commercial land use in any area Commercial land use is the use of land for commercial purposes including building offices, shops, resorts and restaurants as opposed to construction of a residential house. Land can also be used for growing commercial crops, which are crops that are sold instead of used for personal consumption. In all 17 wards, residential uses followed the agricultural uses except ward no 13 and 14 where commercial uses occupied the second position. In ward no 8 and 9 the commercial concentration is maximum which is locally act as the central business district of the urban center. Some small scale handicraft and local raw material based industries are found in the town with very insignificant scale. 


\section{International Journal of Science and Research (IJSR) \\ ISSN (Online): 2319-7064}

Index Copernicus Value (2013): 6.14 | Impact Factor (2015): 6.391

Table 4: Level of concentration of land uses at Panskura Municipality, 2015

\begin{tabular}{|c|c|c|}
\hline \multicolumn{3}{|c|}{ Level of residential concentration area } \\
\hline Class & Ward no. & Level \\
\hline Below 10 & $1,2,3,7,15$ & Low \\
\hline $10-20$ & $6,11,12,13,14,16,17$ & Medium \\
\hline Above 20 & $4,5,8,9,10$ & High \\
\hline \multicolumn{3}{|c|}{ Level of commercial concentration area } \\
\hline Class & Ward no. & Level \\
\hline Below 0.5 & $2,3,4,12,17$ & Low \\
\hline $0.5-1.0$ & $1,6,7,11,16$ & Medium \\
\hline Above 1.0 & $5,8,9,10,13,14,15$ & High \\
\hline \multicolumn{3}{|c|}{ Level of industrial concentration area } \\
\hline Class & Ward no. & Level \\
\hline Below1.0 & $2,5,7,8,9,10.12,13,14,16$ & Low \\
\hline $1.0-2.0$ & $1,4,15,17$ & Medium \\
\hline Above 2.0 & 3,11 & High \\
\hline \multicolumn{3}{|c|}{ Level of agricultural concentration area } \\
\hline Class & Ward No & Level \\
\hline Below1.0 & $4,5,6,8,9,10.11$ & Low \\
\hline $1.0-1.1$ & $1,7,12,13,14,17$ & Medium \\
\hline Above 1.1 & $2,3,15,16$ & High \\
\hline
\end{tabular}

Source: Compiled from table no 3

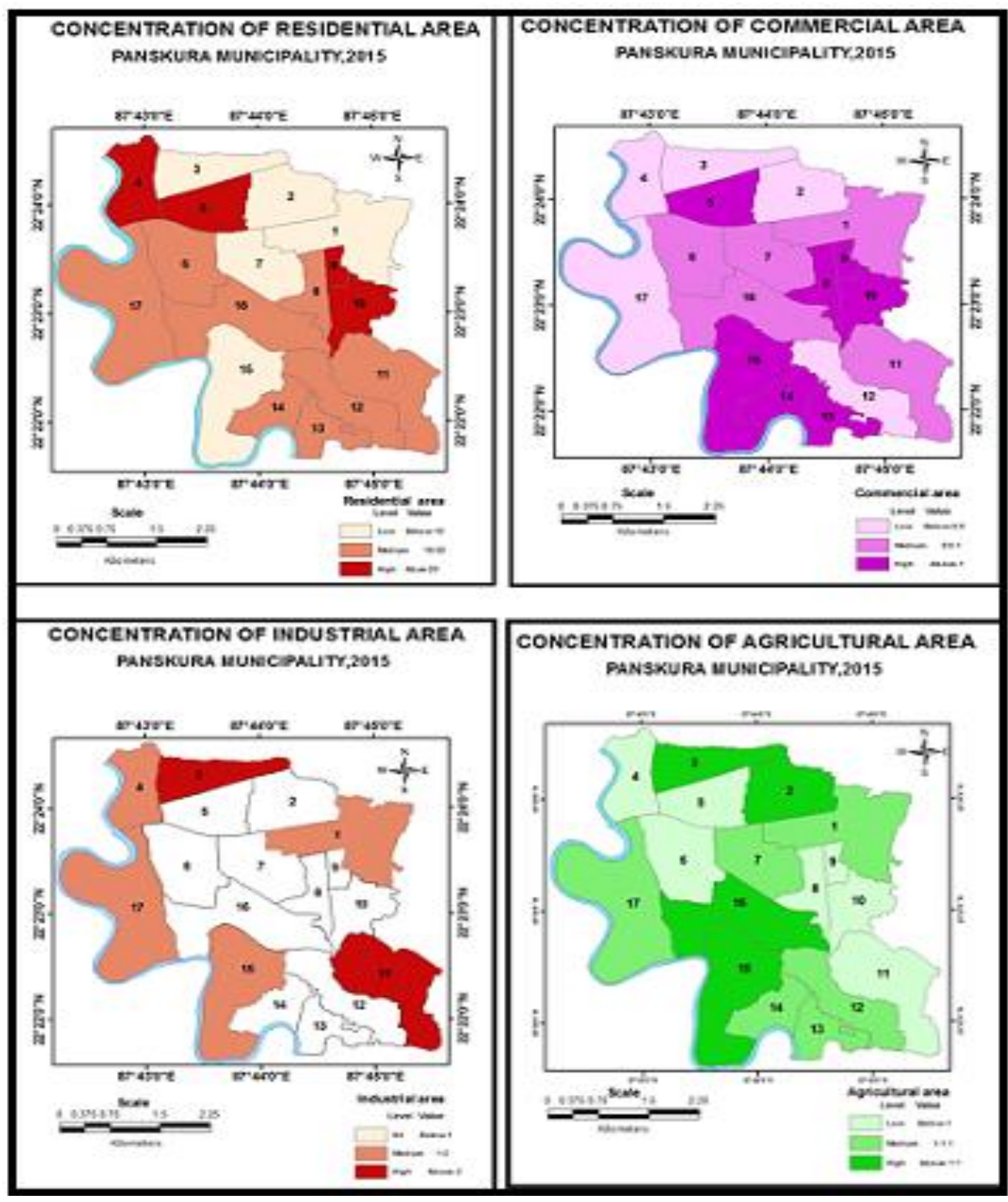

Figure 4: Wardwise concentration of land uses

Volume 5 Issue 6, June 2016 www.ijsr.net

Licensed Under Creative Commons Attribution CC BY 


\section{International Journal of Science and Research (IJSR) \\ ISSN (Online): 2319-7064 \\ Index Copernicus Value (2013): 6.14 | Impact Factor (2015): 6.391}

\section{Landuse Specialization}

The specialization of landuse is concerned with the functions are carried out in order of preference on the land area in the urban process. The specialization focuses on the pattern of uses to identify the location, type, and intensity of land development. The specialization is also designed to help the urban planners to prepare for successful sustainable development land use planning and policy of the area. To analyse the present pattern and nature of land utilization in the study area the following tabular model is developed. It is assumed that if more than 50 percent of land within a bounded area is utilized for any single purpose then the nature of function will be specialized and if no any single function achieved 50 percent level then the functional pattern will be diversified in nature. The utilized pattern of land is arranged in order of their present preferential percentage. On the basis of this assumption, the wardwise functional behavioural pattern of Panskura urban center has been shown in the table 5 below. From table 5 , it is clear that in 65 percent of wards of the municipality where agricultural specialization is the dominant function but residential and diversified functions accounts for 24 percent and 11 percent respectively.

Table 5: Wardwise percentage and land utilization pattern of Panskura municipality, 2015

\begin{tabular}{|c|c|c|c|c|c|c|c|c|c|}
\hline Ward no & $\begin{array}{c}\text { Open } \\
\text { space } \\
(\mathrm{O})\end{array}$ & $\begin{array}{c}\text { Residential } \\
(\mathrm{R})\end{array}$ & $\begin{array}{c}\text { Commercial } \\
(\mathrm{C})\end{array}$ & $\begin{array}{c}\text { Water } \\
\text { bodies } \\
(\mathrm{W})\end{array}$ & $\begin{array}{c}\text { Industrial } \\
(\mathrm{I})\end{array}$ & $\begin{array}{c}\text { Agricultural } \\
(\mathrm{A})\end{array}$ & $\begin{array}{c}\text { Rail area } \\
\text { (RA) }\end{array}$ & $\begin{array}{c}\text { Utilized } \\
\text { pattern }\end{array}$ & Nature \\
\hline 1 & 2.8 & 15.6 & 3.3 & 6.7 & 1.7 & 60.6 & 9.4 & A-R-RA & Agricultural specialization \\
\hline 2 & 0.9 & 19.0 & 0.9 & 0.9 & 0.0 & 78.4 & 0.0 & A-R-C & Agricultural specialization \\
\hline 3 & 0.0 & 13.8 & 2.1 & 0.0 & 6.4 & 77.7 & 0.0 & A-R-I & Agricultural specialization \\
\hline 4 & 9.3 & 50.1 & 0.0 & 2.2 & 3.2 & 35.2 & 0.0 & R-A-O & Residential specialization \\
\hline 5 & 7.4 & 56.8 & 4.2 & 2.1 & 0.0 & 29.5 & 0.0 & R-A-O & Residential specialization \\
\hline 6 & 0.0 & 25.4 & 2.3 & 3.1 & 0.8 & 55.4 & 13.1 & A-R-RA & Agricultural specialization \\
\hline 7 & 2.7 & 22.5 & 3.6 & 3.6 & 0.0 & 56.8 & 10.8 & A-R-RA & Agricultural specialization \\
\hline 8 & 1.8 & 48.9 & 10.9 & 0.0 & 0.0 & 30.9 & 7.5 & R-A-C & Diversified \\
\hline 9 & 0.0 & 72.0 & 13.0 & 0.0 & 0.0 & 0.0 & 15.0 & R-RA-C & Residential specialization \\
\hline 10 & 1.2 & 50.5 & 5.0 & 4.9 & 0.0 & 38.4 & 0.0 & R-A-C & Residential specialization \\
\hline 11 & 2.9 & 40.0 & 3.0 & 0.8 & 4.5 & 48.9 & 0.0 & A-R-I & Diversified \\
\hline 12 & 2.2 & 38.0 & 0.8 & 0.0 & 0.0 & 57.5 & 0.0 & A-R-O & Agricultural specialization \\
\hline 13 & 1.6 & 25.8 & 14.5 & 0.0 & 0.0 & 58.1 & 0.0 & A-R-C & Agricultural specialization \\
\hline 14 & 0.0 & 25.7 & 17.2 & 1.4 & 0.0 & 55.7 & 0.0 & A-R-C & Agricultural specialization \\
\hline 15 & 2.8 & 21.4 & 4.7 & 0.5 & 2.1 & 68.4 & 0.0 & A-R-C & Agricultural specialization \\
\hline 16 & 1.3 & 28.0 & 2.3 & 0.0 & 0.0 & 68.4 & 0.0 & A-R-O & Agricultural specialization \\
\hline 17 & 1.7 & 24.4 & 0.9 & 0.5 & 1.6 & 57.9 & 12.9 & A-R-RA & Agricultural specialization \\
\hline
\end{tabular}

\section{Source: Compiled from table 2}

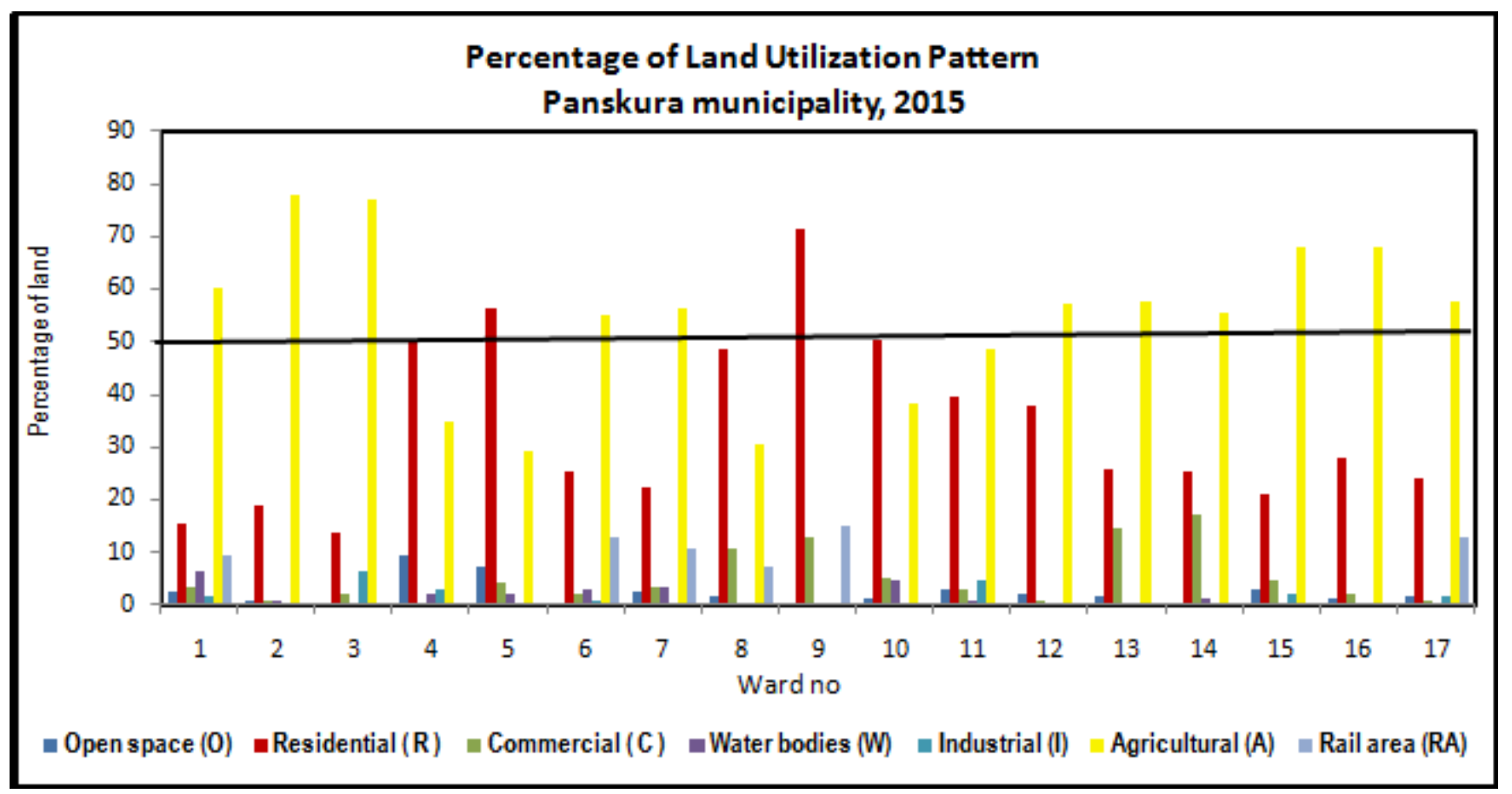

Figure 5: Percentage of land utilization 


\section{Major Findings}

From the above analysis the major findings may be outline as follows:

1) In Panskura municipality the rural functions are dominate over the urban functions.

2) As per 2001census the municipality belongs to Class -II category of town but the secondary activities are less important.

3) The municipality is located near NH-6 and along the South-eastern railway line of Howrah-Kharagpur Section. From the view point of transportation, the municipality has a great prosperity of development.

4) The surrounding area of the municipality is highly productive zone which can support the urban center as a point of export and import.

5) There is enough scope for expansion of the center in all the directions and the multiple economic functions may help the area to be a regional growth point.

\section{References}

[1] Araya ,Y. H. and Cabral,P. (2010), Analysis and Modeling of Urban Land Cover Change in Setúbal and Sesimbra, Portugal, Remote Sens. 2010, 2, 1549-1563; doi:10.3390/rs2061549, www.mdpi.com/journal/remotesensing.

[2] Harold Carter, (1982), 'The study of Urban Geography', Edward Arnold, LTD.

[3] Sinha, B.N. (1968) 'Sirsi: An Urban Study in Application of Research Models, Karnatak University', Dharwar, Mysore 